\title{
AT THE THRESHOLD OF THE FOURTH INDUSTRIAL REVOLUTION: SUSTAINABLE INITIATIVES IN BRAZILIAN INDUSTRIES IN THE CONTEXT OF ANTHROPOGENIC CLIMATE CHANGE
}

João Zaleski Neto Universidade Anhanguera, Brazil E-mail: zaleski@terra.com.br

Sergio Ruggiero Universidade Anhanguera, Brazil E-mail: sergio.ruggiero@aedu.com

Getúlio Kazue Akabane Universidade Anhanguera, Brazil E-mail: sergio.ruggiero@aedu.com

Luis Fernando Zulietti Universidade Anhanguera, Brazil E-mail: zulietti.zulietti@gmail.com

Submission: $24 / 07 / 2013$

Revision: 08/08/2013 Accept: 09/08/2013

\section{ABSTRACT}

The complexity and multiplicity of the possible interactions involved in the phenomenon of anthropogenic climate change make it difficult, even for eminent scientists, to be absolutely certain regarding the occurrence of global climate change and its consequences. Nevertheless, there is a consensus that the crisis is already here. While top-down solutions to this problem are being discussed, this paper addresses the bottom-up approach to reducing GHG emissions. On investigating the behavior of three leading companies in the drinks, food and paint sector, which are proactive specifically in relation to the problem of global climate change and regarding sustainability in general, this study identifies the best practices and documents and disseminates them with a view to their implementation in other organizations. With the use of a tool containing 51 variables, which are each associated with five scenarios, it was possible to identify the 
degree to which the companies meet the challenges imposed by the search for sustainability. In this context, the overall objective of this study was to investigate and identify the behavior of three large companies which are leaders in their sector with regard to sustainability and, specifically, their actions aimed at reducing the effects of anthropogenic climate change.

Keywords: Climate Change, Logistics, Sustainability.

\section{INTRODUCTION}

The humanity has taken the privilege of the relative stability of the environment brought by the Holocene, that is, the interglacial period that began around 10.000 years ago and allowed some complex societies to develop. The human activities, however, have gradually modified the planet weather and its ecosystem. The Alive Planet Report 2012 (Relatório Planeta Vivo, 2012) promoted by the NGO WWF (World Wide Fund for Nature), on its second and most recent version states that the Humanity ecological footprint has exceeded $50 \%$ of the total planet's regeneration capacity.

The ecological footprint estimates the quantity of hectars demanded by the human consumption versus the regenerative planet's potential. Paul Crutzen, the winner of the Nobel Prize in Chemistry of 1995 has concluded that the Earth has entered in a new period called the Anthropocene, in which the humanity is responsible by the planet's climate change. This way, the current world's scientific community main concern is related to the instability of critical biophysics systems on Earth, caused by men's work, which can bring catastrophic consequences to the wellbeing of humanity.

So, with this concern, many scientists, along with Johan Rockström (2009) have asked each other "What are the planetary pre-conditions, which are not negotiable, that must be respected by the humanity, in order to avoid the risk of environmental delete changes or even, catastrophic, in continental to global scales?" The search for the answer to this question have taken them to introduce the planetary limits concept. Such limits are fixed values for measurable variables on the search for keeping safe distances from the considered dangerous levels.

They have proposed new planetary boundaries, whereas three of them were already outmoded, along with the climate change. Thus, this research can be related to the climate change context, for having the goal of contributing with the introductory 
INDEPENDENT JOURNAL OF MANAGEMENT \& PRODUCTION (IJM\&P)

http://www.ijmp.jor.br

V. 4, n. 2, July - September 2013.

ISSN: 2236-269X

DOI: 10.14807/ijmp.v4i2.109

steps for the reduction of the greenhouse gas emission ( $\mathrm{GHG}$ ), resulting from human activities.

\section{GOALS}

One of the ways of finding the solution to this serious environmental crisis faced by civilization is focusing on the leading companies, which are pro-active in the reduction of the greenhouse gas emission issue (GHG), identify the best practice and disseminate them.

It is relevant, investigating these critical factors, which help finding the solution or reducing the anthropogenic climate crisis. This way, the current research proposes the research and evaluation of the behavior of three great business segment leader organizations, which have the awareness for the use of clean technology

The specific goal is identifying success factors, able to be confirmed and imitated, as well as knowing the adjustment degree, where these organizations are found. On the other hand, it is expected to know the critical factors that raise difficulties for the reach of great performance standards.

\section{THE CLIMATE CHANGE}

Since the Industrial Revolution around 1750, the humanity has intensified the use of carbon fuels, such as: wood, coal, turf, gas, among others. The necessity of a cheaper electrical energy was intensified with the increase of the world population, from 700 million people, in the half of the XVIII century to seven billion, in the current days.

The increasing industrialization, the tireless exploration of the natural resources, the necessity of feeding, transporting and warming billions of people in these 260 years have significantly increased, the Carbon Dioxide (CO2) concentration on the atmosphere. The $\mathrm{CO} 2$ is known for being one of the main causers of the greenhouse gases effects.

The Greenhouse effect occurs when, about half of the sun rays, which pass through the atmosphere are absorbed by the Earth and converted to heat, which causes the emission of long waves (infrared) back to the atmosphere where the molecules, including the $\mathrm{CO} 2$, absorb them, bringing the planet's warming, as a consequence. (ROY, 2012). It is also observed that the CO2 is not easily dissipated on the atmosphere, having a long life: approximately $56 \%$ of the whole $\mathrm{CO} 2$ released 
INDEPENDENT JOURNAL OF MANAGEMENT \& PRODUCTION (IJM\&P)

http://www.ijmp.jor.br

V. 4, n. 2, July - September 2013.

ISSN: 2236-269X

DOI: 10.14807/ijmp.v4i2.109

on the burn of fossil fuels by human activity remains in the air and is directly and indirectly responsible for $80 \%$ of the total global warming. When the carbon leaves the atmosphere, it is said that it has gone to the sinkhole.

All living beings are like carbon sinkholes, as well as the oceans and some rocks. For each atmosphere molecule, there are 50 carbon molecules in the oceans. Whenever the dead plants are buried, a lot of $\mathrm{CO} 2$ is stored on the ground, becoming fossil fuels (FLANNERY, 2007). These fossil fuels are used to generate the electrical energy that supports the global economic expansion, or the civilization, as we know it.

The $\mathrm{CO} 2$ is not the only greenhouse gas (GHG) that is generated by human activity, there are, approximately, other thirty similar gases, found on the atmosphere, in smaller quantities. For practical reasons, their effects are evaluated by their conversion in $\mathrm{CO} 2$. After the $\mathrm{CO}$, the methane is the second most powerful GHG, according to the Climate Change understanding.

The methane is 60 times more able to retain the heat than the $\mathrm{CO} 2$; however, it stays a few years in the air. Recent estimation states that the methane is responsible for $15 \%$ to $17 \%$ of the global heating on the XXI century. Other GHG is the nitrous oxide (laughing gas) and the gases of the HFC and CFC categories, the two last were developed by the mankind.

Scientists have established the concentration of $\mathrm{CO} 2$ in 350 ppm, as being an acceptable limit for keeping the climate conditions stable. Currently, this limit has already been exceeded.

The consequences are extremely important, if the Point Of No Return is overtaken. The climate will be more extreme: deep hurricanes, the increasing of the sea level, irregular rains, causing drought and flood, the melting of permanent glaciers. The results will be climate wars, mass migrations, hunger and shortage, according to the International Panel about climate change.

What is the solution for such a crisis? Recently, in the beginning of 2012 Lester Brown, the writer of "Plan B 4.0 Mobilizing To Save Civilization" has proposed a reduction of $80 \%$ on the emission of $\mathrm{CO} 2$ until 2020 , in comparison with the standards of 2006. This can be done by the energy matrix change based on carbon for clean and renewable energy sources, such as wind, solar and geothermal.

Roy (2010) has proposed the reduction of the emission of GHG to $90 \%$ based on the standard of 1990 . For this to happen, he suggests a reduction of $20 \%$ on each 
INDEPENDENT JOURNAL OF MANAGEMENT \& PRODUCTION (IJM\&P)

http://www.ijmp.jor.br

V. 4, n. 2, July - September 2013.

ISSN: 2236-269X

DOI: 10.14807/ijmp.v4i2.109

year, using carbon emission limits and carbon trade for only five years. He affirms that the atmospheric $\mathrm{CO} 2$ must be reduced to $350 \mathrm{ppm}$, but for this, it is necessary, an investment of $2 \%$ to $3 \%$ of the PIB, immediately (STERN apud ROY, 2010), and thereafter, increased, in order to implement the necessary technological changes: basically the carbon energy sources for nuclear fusion, hydroelectric, geothermal, wind, solar, tidal, hydrogen, biomass and co-generation.

Roy (2010) still suggests that all the carbon industry subsidies should be removed and proposes the charging on the use of carbon and GHG emission. The raised funds should be invested in subsidizing the development of clean technologies, carbon free.

It should be noted that another important aspect is the efficient use of energy. Through it, great amounts of GHG may no longer be released into the atmosphere.

Paul Crutzen (2006) notes that between 2001 and 2002 these emissions increased $2 \%$. Recognizing that, by far, the best solution to climate change is through the reduction of $\mathrm{CO} 2$ emissions, he proposes the spread of sulfate particles into the stratosphere to reflect sunlight and cool the planet, a way to artificially emphasize the Albedo Effect which is defined by measuring the reflectivity of the surface of a body. However, the eminent scientist argues that it is unclear whether this solution is environmentally safe.

It is clear that the above-described proposals represent, basically, a top-down approach, where efforts to cut GHG emissions are imposed by government policies. In June 2013 the US federal government presented a plan to combat climate change. On observing that natural disasters cost the United States over US\$100 billion, not including in the figure the health problems caused by extreme climate conditions, President Obama outlined his plan to deal with anthropogenic climate change. He proposes to reduce emissions from thermoelectric power stations, to encourage the generation of solar and wind power, to establish challenging standards for savings in heavy-duty fuel (the second largest source of GHG in the United States) and increase the energy efficiency and reduce the energy wastage in commercial, manufacturing and domestic installations. It also addresses the necessity to prepare for the adverse effects of climate change (CC), investing and supporting initiatives which are resistant to $\mathrm{CC}$, for instance, in hospitals, in the agricultural sector and in logistics operations. Furthermore, the US leader proposes to mobilize the economically strong countries in order to bring them to the negotiating table and 
INDEPENDENT JOURNAL OF MANAGEMENT \& PRODUCTION (IJM\&P)

http://www.ijmp.jor.br

V. 4, n. 2, July - September 2013.

ISSN: 2236-269X

DOI: 10.14807/ijmp.v4i2.109

jointly take key decisions with regard to CC (CLIMATE CHANGE, 2013). In the study reported herein, the approach to reducing GHG emissions is bottom-up, where efforts to reduce the effects of $\mathrm{CC}$ begin within companies through the proactive adoption of better sustainable practices.

\section{LOGISTICS AND SUSTAINABILITY}

The biggest concern is to develop ways to allow symbiotic coexistence between the industrial development and environmental protection. Fleischmann et al. (1997) noted that, frequently, economic and environmental issues are interlaced. They illustrate the example when the rising costs of waste disposal cause the waste reduction to be more economical, along with the formation of consumers' environmental awareness, which represent new market opportunities. Ideally, this induces a combination of ecological and economic advantages as suggested in the concept of sustainable economy.

The focus of corporate strategy has traditionally been on the increase in sales volume through cost reduction leading to the operations' profitability. However, with the growing issue involving the limitation of resources, global warming, emission of greenhouse gases and the health of the consumer, the urgency of enterprises to incorporate the factor of sustainability in their strategies has increased.

Some recent events have shown that this approach: the effect of the oil spill in the Gulf Coast of the United States negatively affected the value of the shares of British Petroleum (MOSS, 2010; GROSS, 2010), the severe penalties imposed on the Shenzhen Energy Group in China after a tanker ship ocean carrying coal slammed into the great reef barrier (HUANG, 2010), and the boycotts, which says that the consumers threatened a major manufacturer of sports equipment after the public found out about child labor (KENYON; CAMPBELL; HAWKEY, 2000) .

With the rise of the concept of the conscious consumer and the incorporation of sustainability as a corporate strategy to reach investors' expectations, the longterm impact that such operations have on the community and the environment are the subject of increasing debate among the community at large (PROKESCH, 2010). With the growth of demands for green products, logistics systems that deliver these products in the hands of consumers should also be green (WU et al., 1994).

It is important to note that there is a potential issue between reverse logistics and green logistics (ROGERS; TIBBEN-LEMBKE, 1999). The reduction of energy 
INDEPENDENT JOURNAL OF MANAGEMENT \& PRODUCTION (IJM\&P)

http://www.ijmp.jor.br

V. 4, n. 2, July - September 2013.

ISSN: 2236-269X

DOI: 10.14807/ijmp.v4i2.109

and environmental pollution associated with better transportation planning and the use of less packaging material can be considered an integral part of the agenda of Green Logistics

The green logistics will change politics, ways of conducting business and behavioral models; will be the new leader of future innovation, job creation, CO2 reductions and energy conservation by creating a competitive advantage in the intermodal industry.

De Brito and Dekker (2003), also identify differences between reverse logistics and green logistics, especially, the recent considerations on the environmental aspects of all logistic activities mainly focused on logistics supply from the producer to the customer. Moreover, it is said that if no goods or materials are being returned, it is probable that the activity is not a reverse logistics.

One of the underlying principles of reverse logistics is to provide effective methods for collecting the products at end of life-cycle and to return the damaged merchandise for reconditioning; associated benefits such as reducing vehicles mileage for lower emission of pollutants and noise, cover the auspices of Green Logistics.

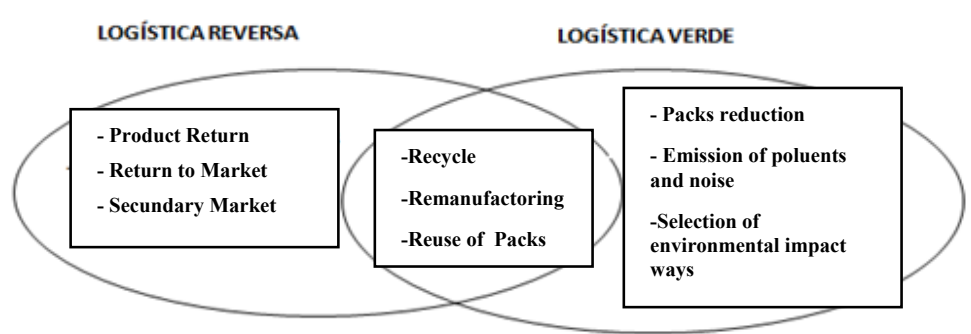

FIGURE 1: Comparison between Reverse and Green logistics.

Source: Rogers and Tibben (2001)

In fact, shipping of returned goods in the supply chain causes the main impact on reverse logistics as it affects the sustainable operation, especially in matters of fuel consumption, mileage, air quality, noise pollution, the safety system and health.

The reduction of supply source strategy must be used to minimize unnecessary emissions and environmental effects, thereby obtaining the possible competitive advantages (WU et al. 1994; MARIEN, 1998). According to the authors, the basic principles of reducing supply sources imply:

a) making things smaller and lighter, thus resulting in lower logistic costs;

b) minimizing the production and distribution operations to reduce the amount of useless materials generated; 
INDEPENDENT JOURNAL OF MANAGEMENT \& PRODUCTION (IJM\&P)

http://www.ijmp.jor.br

V. 4, n. 2, July - September 2013.

ISSN: 2236-269X

DOI: 10.14807/ijmp.v4i2.109

c) recycling of the packaging materials and containers more than once;

d) Replacement for material that is environmentally friendly.

Such strategies can increase end user satisfaction by reducing costs and waste.

Recycling can be considered a good policy, only when the environmental discharges and the resources used for collection, sorting and recycling of material are lower than the environmental discharges and the needed resources to provide the equivalent virgin material, and the necessary resources to accommodate the material safely. Beamon (1999) suggests that the first step of this challenge is to redefine the basic structure of the entire supply chain to accommodate environmental issues and minimize the use of resources and waste emission.

Rodrigue, Slack and Comtois (2001) argue that in one hand, while the spatial and technological development have improved the cost, efficiency and reliability of transport systems for freight and passenger, on the other, the negative environmental impact of transport received widespread recognition by society and is at the center of sustainability issues, especially in urban areas.

In fact, the focus on the supply chain is a broader step in the adoption and development of sustainability, since it considers the processing of the product from the initial raw material to its delivery at the point of consumption (SEURING et al. 2008; LINTON, KLASSON; JAYARAMAN, 2007), including each link business from logistics, strategic planning, information services, sales and marketing, to finance where each manager is responsible for encouraging sustainability initiatives (SARKIS, 1998).

The interaction between sustainability and supply chain is the next critical step, according to recent research in the field of operations and the environment (CORBETT; KLEINDORFER, 2003), operations and sustainability (KLEINDORFER; SINGHAL; WASSENHOVE, 2005).

Although many studies have focused on the idea of sustainability within the context of the supply chain (SEURING; MULLER, 2008; SRIVASTAVA, 2007), there is still a little work concerned on the understanding of the role and importance of logistics organization toward sustainability.

The logistics operation is the integrated management of all necessary activities to move products through the supply chain and logistics costs can be 
INDEPENDENT JOURNAL OF MANAGEMENT \& PRODUCTION (IJM\&P)

http://www.ijmp.jor.br

V. 4, n. 2, July - September 2013.

ISSN: 2236-269X

DOI: 10.14807/ijmp.v4i2.109

defined as "the monetary expression of all kinds of labor consumed during the displacement of the product" (BIN; CHAOYUAN, 2005).

As estimated by the IMF (International Monetary Fund), the average logistics costs constitute approximately $12 \%$ of the annual gross domestic product in the world (BALLOU, 2004). As for the impact it has on the environmental logistics CSCMP ((The Council of Supply Chain Management Professionals, 2008) the logistics produces up to $75 \%$ of the carbon footprint of a company, which means knowing all GHG emissions during the life cycle of a product, that is, knowing the emissions that occurred from the production of its raw material to its final disposal. In the combination of monetary cost and environmental impact, the logistics contributes to the operation to become a key area. Therefore, it is necessary the exploration of new opportunities for strengthening it and making it even more efficient.

For the companies to implement the sustainability strategy in their supply chain in charge of operations, the logistic function must play a prominent role (MOLLENKOPF et al., 2010; GOLDSY; STANK, 2000). For most companies, logistics costs are substantial constituting the second factor in the overall cost structure following the product sale's cost.

Sustainable products is a term used to understand all kinds of products that aim to improve environmental and social quality which is related to the environmental and social implementation patterns, that is, the ultimate goal is to satisfy customers and gain competitive advantage in the market (ABUKHADER; JOHNSON, 2004; BOWEN, 2001; GOLDBACH; SEURING; BACK, 2004; KOVACS, 2004; MEYER; HOFMANN, 2000).

The existing literature on logistics and supply chain also highlights the importance of sustainability (CARTER; ROGERS, 2008) and energy efficiency (HALLDORSSON; KOVACS, 2010) where the need to review the operational level was identified, in which this issue is neglected. Abukhader and Johnson (2004) conducted a comprehensive literature review on environmental and logistics and observed weak links between the implementation of logistics and the environment subjects.

As logistic managers are vital to each functional area, they must understand how each section affects the total supply chain (MURPHY; POIST; BRAUNSCHWEIG, 1996). For the present study, the supply chain refers to the operations made to certify the materials that will compose the goods or services to be 
INDEPENDENT JOURNAL OF MANAGEMENT \& PRODUCTION (IJM\&P)

http://www.ijmp.jor.br

V. 4, n. 2, July - September 2013.

ISSN: 2236-269X

DOI: $10.14807 /$ ijmp.v4i2.109

produced from multiple vendors as well as the transportation of these goods into the manufacturing point. The value chain refers to the company, the management process, and the necessary operations for the manufacture of goods and / or services.

The supply chain refers to the operations that cover processes for the handling and storage of finished products to the consumption point. The reverse logistics presents the idea of sustainability and the end of the product cycle which, gradually, is an important part for providers, consumers and government entities (MEADE; SARKIS; PRESLEY, 2007; PRAHINSKI; KOCABASOGLU, 2006).

\section{METHODOLOGY}

According to Lakatos and Marconi (1995, p. 15): "Search is not just seeking the truth, it is to find answers to posed questions by using scientific methods."

Quantitative research means showing opinions and information through figures to classify and analyze them. It requires the use of resources and statistical techniques (percentage, mean, mode, median, standard deviation, correlation coefficient, regression analysis, etc.). According to Richardson:

The quantitative research can be characterized as an attempt of a detailed understanding of the meanings and situational characteristics presented by respondents, rather than the production of quantitative measures of characteristics or behaviors Richardson (1999, p. 90).

In this work, two methods were used to collect data and information. The first consisted in bibliographical research conducted by consulting books, dissertations, theses, scientific articles and conferences, and access to the documents obtained through databases and libraries.

The second was a statistical study, in which the data was obtained through a questionnaire where the posed questions were of the multiple choice type, some being complemented with the possibility of open-ended responses. These questionnaires were applied at the managers and directors of three major companies in the beverages, paints and food sectors, in the first half of 2012. The five scenarios and questions have been organized by themes: environmental, social, economic and technological, with 13, 9, 10 and 19 questions for each area, respectively. The exhibition and summarization of data was performed using descriptive statistics, through charts, tables and parametric measures. 
The results are related to the study of three large companies from the beverages, paints and food products segments. Such companies were evaluated through a matrix-questionnaire consisting of five adequacy settings, since the scenery with a score of 1 , i.e., when it does not meet the minimum sustainability demanding, passing to the scenery with score 3 , whose disposition partially meets the same requirements, to achieve the maximum score of 5 points, where the organization fully meets the requested requirements.

The 1-5 score was based on the Likert scale, which is a psychometric scale of the most known and used in quantitative research, since it intends to register the level of agreement or disagreement with a statement or set position.

The settings were constructed according to four groups of indicators: environmental, economic, technological and social (with respectively 13, 10, 19 and 9 questions), demonstrating the degree of sustainability in which they find themselves.

\section{RESULTS}

By way of illustrations, in the following table, the comparison between the operating companies in the segments of beverages, paints and food products can be seen. Table 1 below shows the compilation of the provided data, based on collected information with the matrix-questionnaire instrument, where: $Q$ refers to the number of questions that composes each indicator, $T$ means the total number of possible points; $P$ expresses the achieved score and, finally, the percentage column which reflects the ratio $P / T$.

TABLE 1: Comparative data among the researched segments.

\begin{tabular}{|l|r|r|r|r|r|r|r|r|}
\hline \multicolumn{2}{|c|}{} & \multicolumn{2}{|c|}{ BEVERAGE } & \multicolumn{2}{|c|}{ PAINT } & \multicolumn{2}{|c|}{ ALIMENTARY } \\
\hline INDICATORS & $\mathrm{Q}$ & $\mathrm{T}$ & $\mathrm{P}$ & $\%$ & $\mathrm{P}$ & $\%$ & $\mathrm{P}$ & $\%$ \\
\hline ENVIRONMENTAL & 13 & 65 & 49 & 75.4 & 49 & 75.4 & 53 & 81.5 \\
\hline SOCIAL & 9 & 45 & 37 & 82.2 & 43 & 95.5 & 35 & 77.8 \\
\hline TECHNOLOGICAL & 19 & 95 & 53 & 55.8 & ${ }^{*} 43$ & ${ }^{*} 78.2$ & 61 & 64.2 \\
\hline ECONOMICAL & 10 & 50 & 34 & 68.0 & 30 & 60.0 & 42 & 84.0 \\
\hline
\end{tabular}

Source: Research's writers. (2012).

*: from the total of questions about technology of paint segment 8 of them could not be answered.

From Table 1 we can see a slight supremacy of the company in the food industry regarding the environmental indicator, although regarding the social indicator it needs a bigger leap in order to achieve a better level of adequacy. The paint company shows a high commitment, while the others are at a good stage and room for growth in the short term. The indicator shows that technology companies have 
INDEPENDENT JOURNAL OF MANAGEMENT \& PRODUCTION (IJM\&P)

http://www.ijmp.jor.br

V. 4, n. 2, July - September 2013.

ISSN: 2236-269X

DOI: 10.14807/ijmp.v4i2.109

invested as little as possible so that their activities could be carried out, however, much can be done towards competitive advantage by improving processes and operations, and finally, to the economic indicator; the companies in the beverage and paint sectors are not suitable enough, demanding a qualitative leap to considered acceptable levels. Figure 2 shows the results didactically.

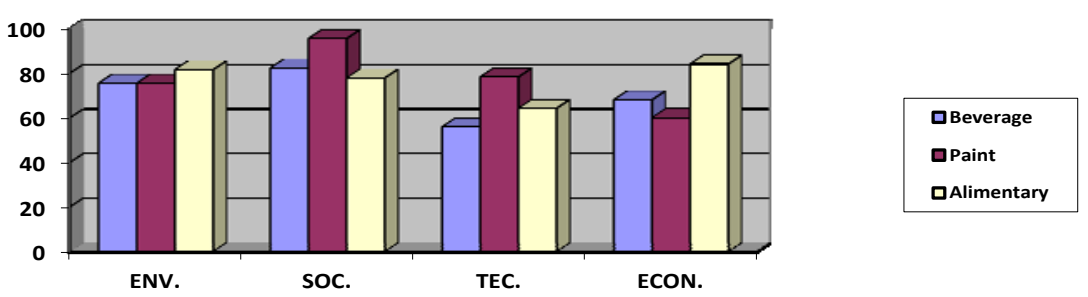

FIGURE 2: Didactic Comparative Visualization of the Indicators.

Source: Research authors (2012).

In the case of large market leaders companies, it can be observed that they are responsible with environmental issues and are committed to the sustainability and reduction of GHG emissions, but the practice of theoretical placements has not been translated into absolute reality, yet.

\subsection{Analysis of Technological Indicators}

As shown in the didactical illustrations of the collected data, although there are different scores among companies (the largest around 22\%), none of them reached the level of $80 \%$ compliance with the requirements of the array-questionnaire, even with the current technology producing medium quantities of GHGs, due to the fact that part of the processes uses energy source based on fossil fuel that emit moderate amounts of GHG. It is observed that during the process, there is the recycling of all technologically possible components / inputs aiming at sustainability.

Considering logistics, companies / third party logistics employ systems to optimize routes and tracking of fleets. These systems show hindrances to proper working. For example, there is a recommendation to drivers to drive as long as possible in speeds that emit the least amounts of GHGs., but there is no monitoring. In relation to the final destination of the products, we can also say that the companies do not have a capable system of reusing all residues, or intend to design their product thinking about its course from the "cradle to grave" in medium term. An important factor noticed, is the ignorance of the meaning of the term carbon footprint, 
INDEPENDENT JOURNAL OF MANAGEMENT \& PRODUCTION (IJM\&P)

http://www.ijmp.jor.br

V. 4, n. 2, July - September 2013.

ISSN: 2236-269X

DOI: 10.14807/ijmp.v4i2.109

which means, they are not aware of GHGs emissions during life cycle of a product, starting from the production of its raw material to its final disposal.

Nitrogen Oxide arises from gas burning in boilers, and the Burning of fossil fuels for power generation is responsible for the emission of huge amounts of gases directly related to global warming (GHGs).

The companies committed to adjust their process in order to reach a Clean Production (CP). This CP seeks to meet society's needs for environmental friendly products through the use of efficient and renewable energy systems. Also, the materials used should not offer risk or threaten the planet's biodiversity. The first steps towards clean production are changes in the production process, adjusting it to international standards regarding efforts for controlling and reducing GHG emissions.

Companies recognize the importance of training and developing employees in clean technologies and the consequent reduction of GHG emissions. The former also includes enhancement in maintenance, such as leakage prevention, less use of toxic substances, and internal recycling systems for the reutilization of water or heat, which would be otherwise, dissipated.

\subsection{Analysis of social indicators}

The different levels of commitment in promoting education in clean technologies probably can be explained from the viewpoints of their leaders, where use of clean technologies implies in competitive advantage, resulting in greater employment generation and income.

As to purely social nature actions both companies presented the best possible results. The beverage company offers an important support to the Vocational Qualification program, held in partnership with Anhanguera college, from Jacareí. This program, which is part of the company, is for underprivileged youth with over 18 , who want to acquire basic knowledge in important areas that help employability, taking into consideration the current market scenario, like: computer administration and logistics classes.

Companies generally commit to educate and train people in the use and knowledge of clean technologies in the medium term, as well as implementing a work security standard, when adopting new clean technologies.

The companies are also committed to the social interaction encouragement in order to improve the assimilation of new knowledge and behaviors related to 
INDEPENDENT JOURNAL OF MANAGEMENT \& PRODUCTION (IJM\&P)

http://www.ijmp.jor.br

V. 4, n. 2, July - September 2013.

ISSN: 2236-269X

DOI: 10.14807/ijmp.v4i2.109

environmental conservation and the use of new clean technologies, as well as implementing policies for the distribution of earnings and profits resulting from the use of new clean technologies in the medium term.

There is a clear concern for the training and development of people regarding the field of clean technologies and the consequent reduction of GHG emissions.

\subsection{Analysis of Economic Indicators}

The growing interest and public awareness regarding environmental issues has led companies from various industries such as beverage, food and inks to consider such issues on its production process.

In the paint market, the pressure to the ecological respect has forced the technological development toward the water-soluble and powder paints. The Brazilian paint industry is clearly defined, comprising three types of companies: large conglomerates (domestic and international), medium-sized companies with administration of familiar character and small and medium industries aimed at serving specific market segments. Considering industrial paints, long-term changes involving manufacturers of resins and pigments are about to happen. For small formulator plants, the reflection is higher for the need of dispersion and mixing equipment replacement, as water-soluble inks require stainless steel equipment.

Significant differences can be seen in the evaluation of the managers of the three companies regarding the relationship between product demands and practices that reduce GHG emissions. According to the beverage industry, the market is not interested in efforts to reduce / not emit greenhouse gases, whereas there are no implications on profitability from such actions. In the paint's segment, a market share (50\%) considers important efforts and the other part ignores or disregards, and must therefore invest in advertising to educate consumers in order to sell their products at a prize price and increase profitability. For the food company, the market clearly perceives efforts from the company to reduce / not emit GHGs and chooses to buy their products, even with a higher price, thereby, increasing their profitability. Thus, the leader of the food company believes that sustainable practices, such as reducing greenhouse gas emissions, contribute to making the demand curve for their products less elastic, that is, the percentage fall in sales decreases for a given increase in their products' price. 
INDEPENDENT JOURNAL OF MANAGEMENT \& PRODUCTION (IJM\&P)

http://www.ijmp.jor.br

V. 4, n. 2, July - September 2013.

ISSN: 2236-269X

DOI: 10.14807/ijmp.v4i2.109

For beverage and food companies, investments to reduce GHG emissions create competitive advantages, while creating an increase in costs for the paint company. The former claim that their debt levels do not make efforts to reduce GHG emissions, while the paint manufacturer says just the opposite, emphasizing that the most committed investments are those for short and medium term.

Investments in GHG reduction by the paint company don't prove themselves to be worth because the return on invested capital occurs only in the long term. However, for the food and beverage companies such investments provide adequate returns in the medium term.

Total Productivity Maintenance is the training focus of the beverage company. Through this system, the machine operator is responsible for maintaining the equipment, and administrative employees must know the whole production process of their products. This management method intends to create a high-performance manufacturing environment, and to reduce losses through continuous improvements in equipment and processes. The effectiveness of the training for the TPM is measured by the increase in productivity and efficacy of the processes.

The market of the food and beverage companies demands products with lower prices, but on the same time that cause less damage to the environment. The leading Brazilian food industry company and a partner, that is a global leader in collection and reutilization of post-consumer waste, have been developing in Brazil, a program that will enable the transformation of thousands of discarded packages in products that replace raw materials in manufacturing processes. This action encourages the collection of post-consumer packages, regardless of their size and brand. The goal is to give a sustainable destiny to these materials, allowing them to be reused as raw material in the production of new products such as purses, bags, backpacks and cases, to be sold in the market.

\subsection{Analysis of environmental indicators}

Concerning the environmental responsibility, in summary, there is a leveling of the understanding of its importance, demonstrated by the obtained data in the search. This is totally understandable because the companies' leaders are constantly driven by rules, regulations and laws, that is, all the necessary regulatory aspects to become companies and markets suppliers which require a pro-active and effective behavior in preserving the environment and in the use of alternative energy sources. 
They perfectly understand that a purchase of their product may be decided by the consumer, when analyzing whether the company acts in a "green" way in its general scope.

\section{FINAL CONSIDERATIONS}

In view of the studied organizations and collected data, many of the answers, regarding the comparison between the segments and the degree of reached maturity, direct efforts, improve activities and enhance procedures for correcting routes.

Surveyed companies seek to become a working model, because they are operating in a highly competitive segment, where market niches which were before despised, currently, make a difference to the maintenance of top position.

All surveyed companies walk toward excellence in performance, however, the indicators currently still reflect a non-appropriate proactivity in relation to the speed with which responses are required for the purpose of preserving the environment, as well as the importance in viewing competitive differentials, particularly with respect to technological aspects.

Research has shown that one way of working, creating and maintaining sustainable features within the industrial aspects, in order to find a solution to this environmental crisis faced by civilization is focusing on leading companies and encourage them to be proactive on the GHG (greenhouse gases) issue. Thus, companies can get the advantage of becoming the first to move into the post-carbon economy, which would make them highly competitive.

It is, specifically, observed that; the spread of sustainable logistics between these companies can be encouraged emphasizing the aspect of reducing GHG emissions in the supply chain and in the process.

\section{REFERENCES}

ABUKHADER, S. M.; JOHNSON, G. (2004) Logistics and the environment: is it an established subject, International Journal of Logistics: Research\&Applications, v. 7, n. 2, p. 137-49.

BALLOU, R.H. (2004) Business Logistics/Supply Chain Management, 5th ed., Pearson Education, Upper Saddle River, NJ.

BEAMON, B.M. (1999) Designing the Green Supply Chain. Logistics Information Management. V. 12, n. 4, p. 332-342, 1999.

BIN, S.; CHAOYUAN, S. (2005) The correlativity analysis between logistics industry and national economy development. Available at: 
www.seiofbluemountain.com/upload/product/201001/12646716644xym9b6o.pdf. Accessed April 8, 2011).

BOWEN FE; COUSINS P. D.; LAMMING R. C; FARUK A. C. (2001) Horses for courses: explaining the gap between the theory and practice of green supply. Greener Management International.

ARTER, C. R.; ROGERS, D. S. (2008) A framework of sustainable supply chain management: moving toward new theory. International Journal of Physical Distribution \& Logistics Management, v. 38 n. 5, p. 360-87.

CLIMATE CHANGE: (2013) and President Obama's action plan. The White House. Washington, 2013. Available at: <http://www.whitehouse.gov/share/climate-actionplan... Accessed: jun. 27.

(The) COUNCIL of SUPPLY CHAIN MANAGEMENT PROFESSIONALS, (2008) Tracking the green miles. Industry Week, v. 267, n. 1, p. 60,

CORBETT, C. J.; KLEINDORFER, P. R. (2003) Environmental management and operations management: introduction to the third special issue. Production and Operations Management, v. 12, n. 3, p. 287-9.

CRUTZEN, P. J. (2006) Albedo enhancement by stratospheric sulfur injections: a contribution to resolve a policy dilemma? Climatic Change. v. 77, p 211-219.

DE BRITO, M. P.; DEKKER, R. (2003) A Framework for Reverse Logistics. Erasmus Research Institute of Management Report Series Research In Management, 2003

DEY, A.; LaGUARDIA, P.; SRINIVASAN, M. (2011) Building sustainability in logistics operations: a research agenda. Management Research Review, v. 34, n. 11, 2011 p. 1237-1259.

FLANNERY, T. (2007) Os Senhores do Clima. Rio de Janeiro. Editora Record.

FLEISCHMANN, M.; BLOEMHOF-RUWAARD, J. M.; Dekker, R.; VAN der LAAN, E.; VAN NUNEN, J. A. E. E.; Van WASSENHOVE, L. N. (1997) Quantitative Models for Reverse Logistics: A Review. European Journal of Operational Research. n. 103, p17.

GOLDBACH M.; SEURING S.; BACK S. (2003) Coordinating sustainable cotton chains for the mass market - the case of the German mail order business OTTO. Greener Management International.

GOLDSBY, T. J.; STANK, T. P. (2000) World class logistics performance and environmentally responsible logistics practices. Journal of Business Logistics, v. 21, n. 2, p. 187-208.

GROSS, D., (2010) Death on our shores. Newsweek, v. 155, n. 26, p. 36-9.

HALLDORSSON, A.; KOVACS, G. (2010) The sustainable agenda and energy efficiency logistics solutions and supply chains in times of climate change. International Journal of Physical Distribution \& Logistics Management, v. 40, n. $1 / 2$, p. 5-13.

HUANG, C., (2010) How much damage did the Seng Neng 1 do the great barrier reef. Christian Science Monitor, April 14, p. 1.

KENYON, P.; CAMPBELL, F.; HAWKEY, E. (2000) Gap and Nike: no sweat. BBC News. 
KLEINDORFER, P. R., SINGHAL, K.; Van WASSENHOVE, L. N. (2005), Sustainable operations management. Production and Operations Management, v. 14, n. 4, p. 482-92.

KOVACS G. (2004) Framing a demand network for sustainability. Progress in Industrial Ecology: An International Journal.

LAKATOS, E. M.; MARCONI, M. A. (1995) Metodologia do trabalho científico. São Paulo: Atlas.

LINTON, J. D.; KLASSEN, R. B.; JAYARAMAN, V. (2007) Sustainable supply chains: an introduction. Journal of Operations Management, v. 25, n. 6, p. 1075-82.

LOURENÇO, H. R.; SOTO, J. P. (2002) A Recoverable Production Planning Model. Working Paper, Grupo de Recerca en Logistica Empresarial, Barcelona.

MARIEN, E. J. (1998) Reverse Logistics as a Competitive Strategy. The Supply Chain Management Review. v.2, n. 1, p. 43-52.

MEADE, L.; SARKIS, J.; PRESLEY, A. (2007) The theory and practice of reverse logistics. International Journal of Logistics Systems and Management, v. 3, n. 1, p. 56-84.

MEYER A.; HOFMANN P. (2000) Other thoughts; other results? - Remei's bioReorganic cotton on its way to the mass market. Greener Management International.

MOLLENKOPF, D.; STOLZE, H.; TATE, W. L.; UELTSCHY, M. (2010) Green, lean, and global supply chains. International Journal of Physical Distribution \& Logistics Management, v. 40, n. 1/2, p. 14-41.

MOSS K., R. (2010) It's time to take full responsibility. Harvard Business Review, v. 88, n. 10, p. 42.

MURPHY, P. R.; POIST, R. F.; BRAUNSCHWEIG, C. D. (1996) Green logistics: comparative views of environmental progressives, moderates, and conservatives. Journal of Business Logistics, v. 17, n. 1, p. 191-211.

PRAHINSKI, C.; KOCABASOGLU, C. (2006) Empirical research opportunities in reverse supply chains. Omega, v. 24, n. 6, p. 519-32.

PROKESCH, S. (2010) The sustainable supply chain. Harvard Business Review, v. 88, n. 10, p. $70-2$.

RICHARDSON, R. J. (1999) Pesquisa Social: métodos e técnicas. São Paulo: Atlas.

ROCKSTRÖM, J. et al. (2009) Planetary Boudaries: exploring the safe operating space for humanity. Ecology and Society [on line], v. 14, n. 12. Disponível em: http://www.ecologyandsociety.org./vol14/iss2/art32/ Acesso: 15/03/2012.

RODRIGUE, J. P.; SLACK, B.; COMTOIS, C.; (2001) Green Logistics (The Paradoxes of). Published in Brewer, A.M., Button, K.J., Hensher, D.A. (eds), The Handbook of Logistics and Supply-Chain Management.

ROGERS, D. S.; TIBBEN-LEMBKE, R. S. (1999) Going Backwards: Reverse Logistics Trends and Practices. Reverse Logistics Executive Council, Pittsburg, PA.

ROY, P. (2010) India: Crisis and Opportunity: Climate Change, Climate Innovation. New Delhi. 
ROY, P. (2012) Climate Change, Climate Innovation, Global Opportunities. Iguaçú Falls.

SARKIS, J., (1998) Evaluating environmentally conscious business practices. European Journal of Operational Research, v. 107, n. 1, p. 159-74.

SEURING, S.; MULLER, M. (2008) From a literature review to a conceptual framework for sustainable supply chain management. Journal of Cleaner Production, v. 16, n. 15, p. 1699-710.

SEURING, S.; SARKIS, J.; MULLER, M.; RAO, P. (2008) Sustainability and supply chain management - an introduction to the special issue. Journal of Cleaner Production, v. 16, n. 15, p. 1545-51.

SRIVASTAVA, S. K. (2007), Green supply chain management: a state of the art literature review. International Journal of Management Reviews, v. 9, n. 1, p. 53-80.

TIBBEN-LEMBKE, R. S.; ROGERS, D. S. (2002) Differences Between Forward and Reverse Logistics in a Retail Environment. Supply Chain Management. v. 7, n. 5, p. 271-282.

WU, H. J.; DUNN, S. C. (1994) Environmentally Responsible Logistics Systems. International Journal of Physical Distribution \& Logistics Management. v. 25, n.2, p. 20-38. 